九州大学学術情報リポジトリ

Kyushu University Institutional Repository

\title{
Underground Buddhism : The Subterranean Landscape of the Ise Shrines
}

Moerman, Max D.

Barnard College, Columbia University : Professor, Departmet of Asian and Middle Eastern Cultures

https://doi.org/10.5109/1924411

出版情報: Journal of Asian Humanities at Kyushu University. 3, pp.115-128, 2018-03. Kyushu University, School of Letters, Graduate School of Humanities, Faculty of Humanities バージョン:

権利関係 : 


\title{
Underground Buddhism: The Subterranean Landscape of the Ise Shrines
}

\author{
D. MAX MOERMAN
}

or the past one hundred and fifty years, the Ise Shrines (Ise Jingū 伊勢神宮) have been presented as the homeland of an indigenous religion untouched by Buddhist traditions. Although more recent scholarship has revealed this image to be an ideological fantasy invented by nineteenth-century Nativists and perpetuated by the Japanese government until the end of the Pacific War, it nevertheless remains the common understanding of Ise, an understanding that continues to be promoted by the shrines today. The policy of the Meiji government (1868-1912) known as the "separation of Shinto and Buddhism" (shinbutsu bunri 神仏分 離), which segregated religious deities, clergy, institutions, and images into the mutually exclusive categories of Buddhist or Shinto, was a political act that sought not only to change the status, structure, and administration of Ise, but also to erase its past. For the previous thousand years, Buddhist practices, practitioners, texts, objects, and aspirations were integral to Ise's religious and institutional culture. The work of such scholars as Abe Yasurō, Itō Satoshi, Kadoya Atsushi, Fabio Rambelli, and Mark Teeuwen has revealed the centrality of Buddhist traditions in formulating the pantheon, doctrine, and ritual at Ise. In doing so, these scholars have established a new intellectual and literary history of Ise that focuses on the hermeneutic strategies and esoteric texts that "saw their final redactions in the thirteenth and fourteenth centuries." Abe Yasurō, for example, has studied the temple archives of Shinpukuji 眞福寺 to examine "Shinto as written representation" and analyze "medieval Shinto as text." And Mark Teeuwen has charted the "fluid body of cross-referencing texts" that constitute what he calls the genre of "Ise literature."

This article seeks to complement and complicate this new history of Ise by shifting our attention from doctrinal elaborations of distinct priestly lineages to the material objects and ritual acts created by collaborative networks of institutional groups that have been assumed conventionally to be rivals. The ritual practices and material culture produced by and for the priestly lineages of the Ise Shrines established a sustaining relationship between the gods and the buddhas at the ground level, and lay the necessary substructure for later Buddhist developments at the Ise Shrines.

\section{Ise as a Buddhist Construction}

Buddhist institutions, practices, discourses, and rep-

\footnotetext{
An earlier version of this article appeared in Japanese in Moerman, "Chichū no Bukkyō," 2016.

Teeuwen and Breen, A Social History of the Ise Shrines, p. 61.

Abe, "Shintō as Written Representation."

Teeuwen and Breen, A Social History of the Ise Shrines, p. 61.
} 
resentations were a part of Ise's religious landscape since at least the eighth century. According to the Shoku Nihongi 続日本紀, the state history composed in 797, Takidaijingūji 多気大神宮寺, the shrine-temple (jingu $\bar{j} i$ 神宮寺) of the imperial princess at Ise (saigu $\bar{u}$ 斉 宮), was established in Watarai-gun 度会郡in 698 to better serve the shrines. ${ }^{4}$ In 766 , an imperial envoy was sent to "the temple of the Great Deity of Ise" with the gift of a life-size (jöroku 丈六) statue of a buddha to serve as its principal icon. ${ }^{5}$ In the same year, the court ordered that Ōkasedera 鹿瀬寺 be established as the state-sponsored temple of the Ise Shrines in perpetuity. ${ }^{6}$ Yet the earliest records of Ise Shrine ritual, the Protocols of the Imperial Great Shrine (Kötaijingū gishikichō 皇大 神宮儀式帳) of 804, declare such basic Buddhist terms as "buddha," "sutra," "pagoda," "monk," "temple," and "lay practitioner" as taboo (imi 忌). 7 The prohibitions at Ise of Buddhist vocabulary, practices, and practitioners at particular religious sites and ritual occasions suggest at once a tension and an intimacy between shrine and temple traditions. The isolation of kami and buddhas at Ise indicates that a difference was drawn between the traditions, and yet this difference remained in need of explanation.

It is this complex relationship that the Buddhist monk Mujū Ichien 無住一圓 (1227-1312) attempts to explain in the opening tale of his thirteenth-century Collection of Sand and Pebbles (Shasekishī 沙石集):

While I was on a pilgrimage to the Great Shrine during the Kōchō Era [1261-1264], an official explained to me why words associated with the Three Treasures of Buddhism were forbidden at the shrine, and why monks could not closely approach the sacred buildings. In antiquity, when this country did not yet exist, the deity of the Great Shrine, guided by a seal of the Great Sun Buddha (Dai Nichi Nyorai 大日如来) inscribed on the ocean floor, thrust down her august spear. Brine from the spear coagulated like drops of dew, and was seen from afar by Mara, the Evil One, in the Sixth Heaven of Desire. "It appears that these drops are forming into the land where Buddhism will be propagated and people will escape from the round

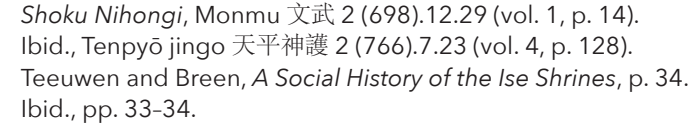

of birth-and-death," he said, and came down to prevent it. Then the deity of the Great Shrine met with the demon king and said, "I promise not to utter the names of the Three Treasures, nor will I permit them near my person.” Being thus mollified, he withdrew. ... Outwardly the deity is estranged from the Dharma, but inwardly she profoundly supports the Three Treasures. Thus, Japanese Buddhism is under the special protection of the deity of the Great Shrine.... Since all of this arose by virtue of the seal of the Great Sun Buddha on the ocean floor, we have come to identify the deities of the Inner and Outer Shrines with the Great Sun Buddha of the Two-Part Mandala; and that which is called the Heavenly Rock Cave is the Tusita Heaven of the Buddha Maitreya. ${ }^{8}$

The true history of Buddhism at Ise, according to $\mathrm{Mu}-$ jū's tale of origins, is thus purposely concealed. It is a history that reaches back before the Japanese islands even existed, yet it remains forever hidden, buried deep beneath the waves. Mujū's answer to an apparently inexplicable situation - the prohibition of Buddhist institutions, individuals, discourses, rituals, and representations at the Ise Shrines-is to reformulate the classical myth of Japanese cosmogony to expose the apparent ban on Buddhism as a clever ruse concocted by the Sun Goddess to thwart the archenemy of the Dharma and establish Ise as the secret headquarters of a national Buddhist underground. What appears on the surface as taboo is shown to have a deeper underlying meaning, inscribed on the ocean floor by the Great Sun Buddha before the Land of the Gods was even formed, representing not a prohibition but rather a promise of protection and preservation. The implication of this primordial arrangement between the Sun Goddess Amaterasu 天照 and the Great Sun Buddha reveals the sacred landscape of the Ise Shines as essentially Buddhist. Beneath the outward appearance of the two Ise Shrines lies the underlying structure of the Mandala of the Two Realms (ryōkai mandara 両界 曼茶羅): the Womb Realm (taizōkai 胎蔵界) and Diamond Realm (kongōkai 金剛界), the substrate of all forms of esoteric Buddhist thought and practice. The Heavenly Rock Cave (Ama no Iwato 天岩戸), behind

8 Mujū Ichien, Shasekishū, pp. 59-61; Morrell, Sand and Pebbles, pp. 72-74. 
which Amaterasu concealed herself in the Age of the Gods, is none other than the heavenly cavern of Tusita, in which Maitreya (Jp. Miroku 弥勒), the Buddha of the Future, awaits the dawning of a new Buddhist age.

Mujü's double reading of Ise's sacred landscape represents an advanced stage of a Buddhist discourse on the shrines and their deities that had developed over a period of some two hundred years. As early as the mid-eleventh century, the monk Seizon 成尊 (10121074) of the Shingon 真言 school had equated the Sun Buddha with the Sun Goddess. ${ }^{9}$ In the late twelfth century, texts such as the Reading and Explanation of the Nakatomi Purification Formula (Nakatomi harae kunge 中臣袚訓解) and the Ritual Manual for the Worship of Amaterasu (Tenshō Daijin giki 天照大神儀軌) marked "the beginning of a flood of writings that offered a broad array of new interpretations of the site of Ise, its shrines and its kami."10 Yet, as Mujū's account suggests, it was not until the medieval period that the Ise Shrines were fully explained as a fundamental and foundational Buddhist site in a wide body of literature that circulated beyond Ise's clerical elites. This Buddhist vision of Ise, however, is presented in medieval sources less as an historical development than as an original condition, like the seal of the Great Sun Buddha inscribed at the bottom of the ocean, always already there. Let us take a step back from this fully formed textual claim to examine earlier practices that contributed to the conditions of its possibility: practices carried out in the late twelfth century by members of Ise's sacerdotal lineages that identify the individual and institutional agents responsible for the transformation of the religious culture and religious landscape of the Ise Shrines. An analysis of the archeological evidence allows for an understanding of Ise that has long been buried and even longer obscured, not only by a century of ideological and intellectual assumptions about the difference between temple and shrine traditions, but also by more recent approaches to the study of Japanese religion that prioritize doctrinal discourse over material culture. The archeological evidence, however, suggests a more complicated and vibrant picture, in which a network of actors working

9 On Seizon's text, Shingon fuhō san'yōshō (T 2433), see lyanaga, "Medieval Shintō as a Form of 'Japanese Hinduism,"' pp. 269-74; and Andreeva, Assembling Shinto, pp. 25-27.

10 Teeuwen and Breen, A Social History of the Ise Shrines, p. 61. On the Nakatomi harae kunge, see Teeuwen and van der Veere, Nakatomi Harae Kunge; on the Tenshō Daijin giki, see Teeuwen and Breen, A Social History of the Ise Shrines, pp. 61-63. across religious traditions, institutions, and lineages collaborated to produce the devotional activities and material objects necessary to assure the preservation of their faith and the salvation of their loved ones.

\section{Underground Buddhism}

Compared to the underwater seal of the Great Sun Buddha and Amaterasu's undercover support of the Three Treasures, these activities and objects represented a different kind of underground operation and a different sort of textual practice. In the second half of the twelfth century, prominent members of the priestly lineages of the Ise Shrines-the Watarai 度会, Arakida 荒木田, Isobe 磯部, and Ōnakatomi 大中臣-buried consecrated copies of Buddhist sutras, dharanis, and mandalas, together with sacred objects and images, in the earth at sites in the immediate vicinity of the Inner and Outer Shrines. The burial of sutra texts and other objects of Buddhist visual and material culture was an open secret, a public act in an age of personal crisis. For the twelfth century represented, to many Japanese, a crucial turning point in the history of Buddhism: the onset of mappo 末法, the final degenerate age of the Buddhist Dharma, in which both the availability of Buddhist texts and the ability of people to realize their teachings would reach their lowest points. The ineluctable decline of the Dharma presented soteriological problems for both the tradition and the individual. The death of the Dharma challenged, of course, the very existence of Buddhism, and required acts of protection and preservation to ensure its survival. But mappō also had implications for individual practitioners for whom personal salvation became increasingly difficult as the source of the teachings receded into an inaccessible past, and the spiritual capabilities of humans diminished. Although a concern with mappō clearly informs the practice of sutra burial, the preservationist impulse was not necessarily the sole motivating factor. Inscriptions accompanying sutra burials also express the hope that, due to this meritorious act, the donor (or other individuals to whom the merit is being transferred) will be reborn in the Pure Land of the buddha Amitäbha (Jp. Amida 阿弥陀) or in Maitreya's Tusita Heaven. Sutra burials illustrate the belief that the future of the Dharma and the future of the individual are linked, and that this critical juncture in the salvation of both Buddhism and Buddhists could be addressed with the same 


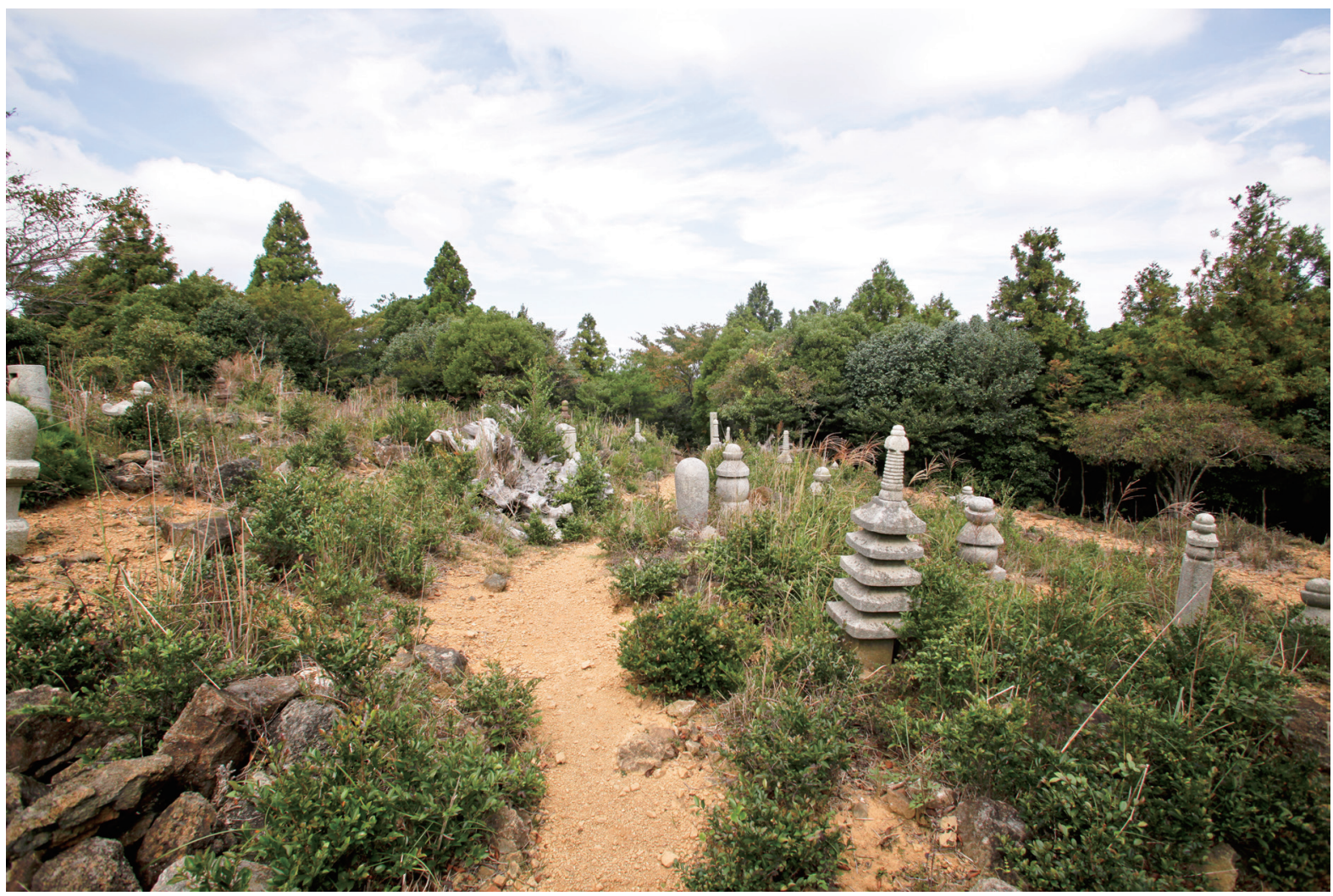

Figure 1. Site of the Kyōgamine sutra burials on Mt. Asama. 1156-1186, Heian period. Photograph by Suzuki Risaku. Courtesy of Suzuki Risaku.

religious practice. Sutra burials offered the ritual strategies and material means whereby the end-time could be prepared for, and paradise secured.

By the early twelfth century, sutra burials could be found in every province of the country from Satsuma to Dewa. ${ }^{11}$ They were carried out most commonly at or near temples, shrines, or sacred mountains, and performed either by Buddhist monks or laity under monastic supervision. What makes the Ise burials so notable and so surprising, given the received understanding of Ise, is that they were performed by members of the priestly lineages of the Inner and Outer Shines, individuals commonly thought to abhor all things Buddhist, and directed toward the Buddhist salvation of the Ise priests themselves. The direct involvement of Ise's sacerdotal

11 For the chronology and locations of these sutra mounds, see Seki, Kyōzuka to sono ibutsu, pp. 37-53. lineages in Buddhist practices had a long history. As early as the tenth century, the priests of the Ise Shrines built Buddhist temples to gain salvation after death, took the tonsure and became Buddhist monks in the final years of their lives, and received Buddhist funerals and memorial services. Rengeji 蓮華寺, Rendaiji 蓮 台寺, and Shakusonji 釈尊寺 served as the family temples of the Ōnakatomi, who occupied the central Office of the Great [Ise] Shrines (Daijingūji 大神宮司); Jōmyōji 常明寺 and Jōshōji 常勝寺 were the family temples of the Watarai, the priests of the Outer Shrine; and Dengūji 田宮寺 and Tengakuji 天覺寺 were the family temples of the Arakida, who served as priests of the Inner Shrine. ${ }^{12}$ The excavated materials from the sutra burials at Ise, however, provide physical evidence of the depth of the Buddhist faith of these lineages and a material record of the construction of Ise as a site of Buddhist texts and objects, Buddhist rituals and clergy, and Buddhist aspirations and ideals. It is a record,

12 On the shrine-temples of Ise, see Hagiwara, "Ise jingū to bukkyō," pp. 231-39. 
moreover, of great historical specificity in which the names, dates, and motivations of the practitioners are inscribed in ink and clay in the hopes of outlasting the Final Age.

The sutras buried at Ise were transcribed according to strict ritual protocols and then interred underground to protect and preserve the Dharma until the arrival of the buddha Maitreya some 5.67 billion years in the future. As Ise's Heavenly Rock Cave is none other than Maitreya's Tusita Heaven (as Mujū explains), the sacred ground of the shrine's landscape is an ideal site for securing the sutras in anticipation of the advent of the future buddha. The scriptures and related deposits were produced in a variety of materials - paper, copper, bronze, glazed and unglazed ceramic - and were buried at nine different sites between the years 1156 and 1186. ${ }^{13}$ Our discussion will be limited, however, to the two principal sites that most clearly document the role of Ise's priestly lineages in such practices. One group of sutras, transcribed in ink on paper, placed into cylindrical stupa-shaped containers made of copper, and then encased in secondary outer ceramic vessels, was buried at what is known as the Mt. Asama Kyōgamine 朝熊山経ヶ峰 sutra mounds, 542 meters above sea level, east of the Inner Shrine (figure 1). Like many other examples across Japan, the Mt. Asama materials were interred in small underground chambers lined and sealed with stones and marked, like a grave, with earthen mounds and stone stupas.

A second group of sutras, signaling perhaps an even more explicit concern with the preservation of the Dharma, was inscribed on clay tiles that were glazed, fired, and then buried at three sites in the hills just west of the Outer Shrine, known as the Komachi 小町, Bodaisan jingūji 菩提山神宮寺, and Eitaizan Kyōgamine 永代山経ヶ峰 sutra mounds (figure 2). ${ }^{14}$ These burials speak to more than the historical and soteriological anxieties of the age. They also specify Ise as the site where such anxieties were expressed and where, it was hoped, they could be conquered as well.

13 Ceramic sutra containers with inscriptions dated Hōgen 保元 1 (1156) and Bunji 文治 2 (1186) have been excavated from Mt. Asama sites 5, 8, and 10c. Kodama, Ise Yamada no gakyō, p. 10.

14 For a comprehensive history of these sites and their scholarship, see ibid., pp. 29-72.

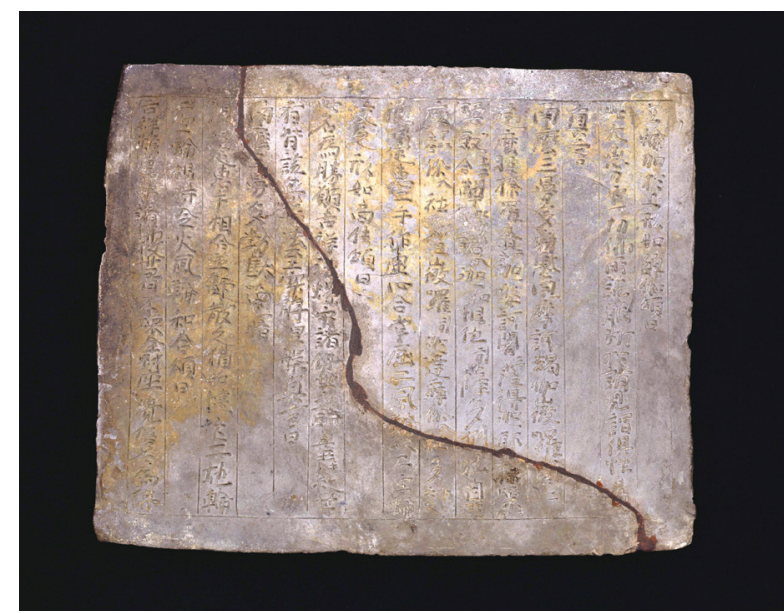

Figure 2. Clay tile inscribed with Buddhist texts. 1174, Heian period. Glazed terracotta. $24 \mathrm{~cm} \times 30 \mathrm{~cm}$. Excavated from the Komachi sutra mound, Ise, Mie Prefecture. Collection Tokyo National Museum, acc. no. J-36661.

\section{Preparing for the Pure Land}

In 1959, a major typhoon struck the Ise region and uprooted numerous trees on Mt. Asama. The storm damage exposed a large group of sutra burials within a thirty-meter-square area beside the Shingon temple of Kongōshōji 金剛證寺 near the summit of the mountain. Excavations, carried out between 1960 and 1963, have identified forty-three burial sites, in rectangular plots measuring between one and two meters by two to two and a half meters, spaced approximately three meters apart. The sites, dating from 1156 to 1186, contained sutras housed within cylindrical copper vessels, which were themselves encased within outer ceramic vessels. In addition to the sutras and their containers, a wide range of other items also were included in these burials, such as bronze mirrors engraved with Buddhist images, ceramic lotus-form pedestals for Buddhist images, knives, scissors, flints, needles, covered dishes of porcelain and lacquer, plates of various sizes, tea bowls, flower vases, sake decanters and cups, cypress fans, glass beads, and coins. ${ }^{15}$ As rich and varied as the objects themselves, the individuals responsible for the

15 The contents are itemized in Seki, Heian jidai no maikyō to shakyō, pp. 457-58. The citations of sutra burial inscriptions that follow all refer to the transcriptions included in the appendix to Seki's volume. 

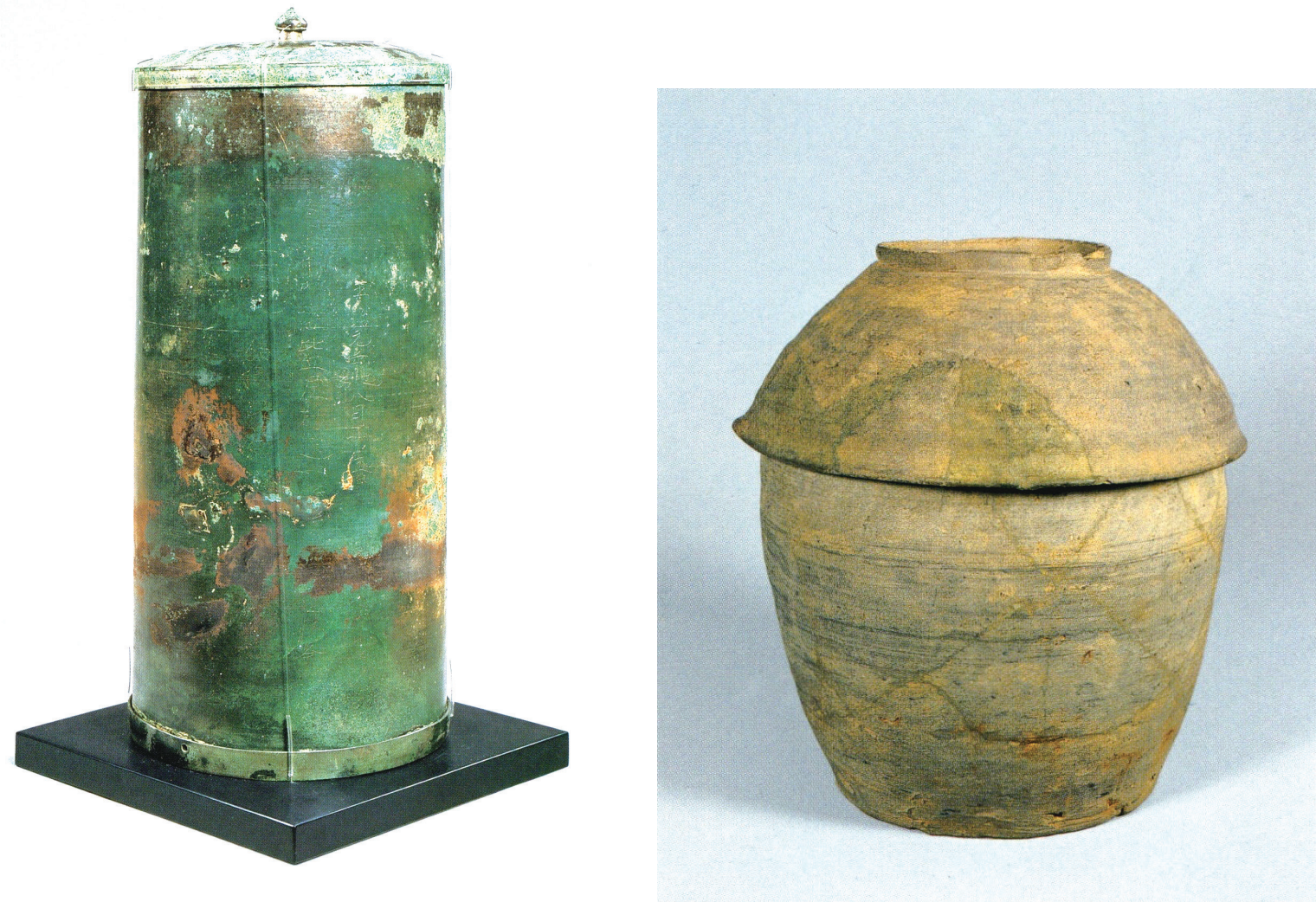

Figure 3a. Sutra case (left) and outer case (right). 1159, Heian period. Copper, ceramic. Sutra case: Diam. $12.2 \mathrm{~cm}, \mathrm{H} 29.6 \mathrm{~cm}$; outer case: H $25.7 \mathrm{~cm}$. Figs. 3a and 3b, excavated from Mt. Asama Kyōgamine sutra mound no. 3, Ise, Mie Prefecture. Collection Kongōshōji, Mie Prefecture. From Tōkyō Kokuritsu Hakubutsukan, Ise jingū to kamigami no bijutsu, pp. 56-57, fig. 26.

Mt. Asama burials reveal a complex network of familial and institutional lineages that formed the texture of the religious communities of Ise in the late twelfth century. The excavated materials not only identify Ise as a site for the preservation of the Dharma, they also identify the head priests (negi 襧宜) of the Ise Shrines as the individuals seeking Buddhist salvation.

Among the earliest and most revealing of the Mt. Asama burials is a copper sutra case and ceramic outer case (figure 3 a) dated by inscription to Heiji 平 治 1 (1159).8.15 containing thirteen scrolls, including the Lotus Sutra (Myōhō renge kyō 妙法蓮華経), which in the East Asian tradition includes the Sutra of Innumerable Meanings (Muryōgi kyō 無量義経) and the Sutra of Meditation on the Bodhisattva Universal Virtue (Kanfugen bosatsu gyōbō kyō 観普賢菩薩趐望経) as its opening and closing sections. The sutras-transcribed and dated the previous day by the nuns Benkaku 弁覚,
Myōi 妙意, Ryōjitsu 良実, Jōzen 定禅, and Jōi 定意 from Jōkakuji 常覚寺, a temple located in the Yamada 山田region of Watarai District-were dedicated by the five nuns so that members of the Ōnakatomi and Watarai lineages might, according to their inscription, "avoid rebirth in the Six Realms and all become buddhas and attain the way." ${ }^{\prime 16}$ The sponsor is identified as the nun Shinmyō 真妙, from Jōshōji 常勝寺, another temple of the Watarai lineage in the same region, and the names of another ten monks who contributed to the project, in the hope of "forming karmic connections (kechien 結縁)," are also listed. The central purpose of these pious efforts of so many Buddhist nuns and monks was to guarantee the post-mortem salvation of the former

16 The inscription, which appears at the end of the third chapter of the Lotus Sutra, is transcribed in ibid., p. 456 (no. 121). 


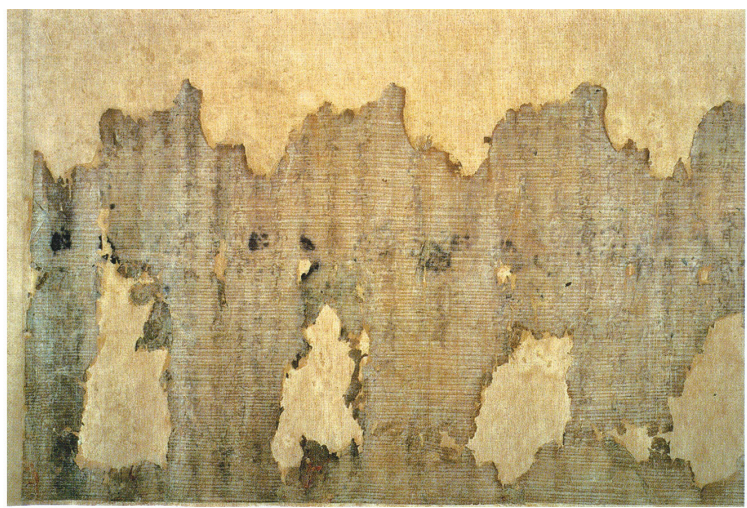

Figure $\mathbf{3 b}$. Sutra of Meditation on the Bodhisattva Universal Virtue and inscription. 1159, Heian period. Handscroll, ink on paper. H $23.4 \mathrm{~cm}$. Contained within sutra case (fig. 3a).
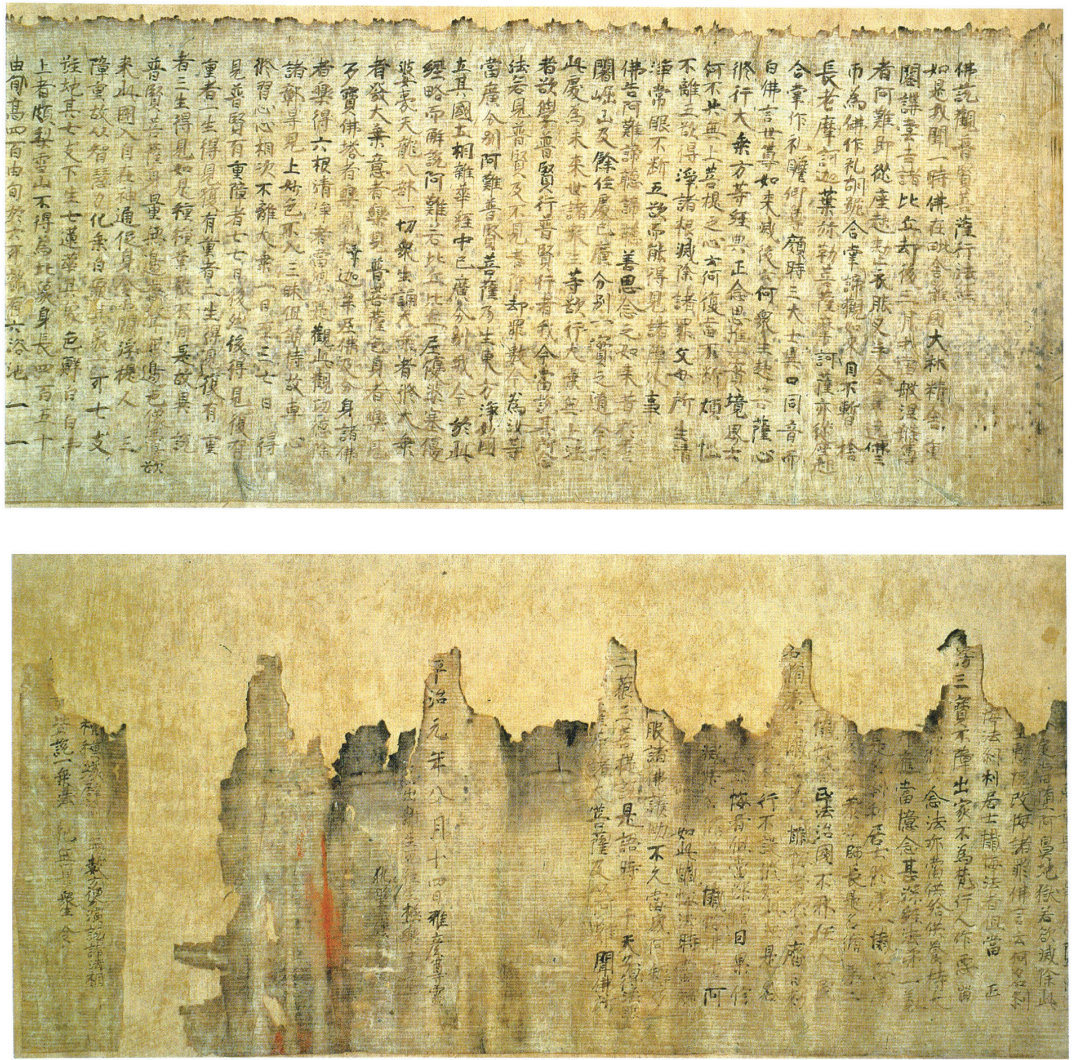

head priest of the Outer Shrine of Ise, Watarai Masahiko 度会雅彦 (d. 1159), who had died exactly four months earlier. An inscription on the back of the Sutra of Meditation on the Bodhisattva Universal Virtue states that the sutras were "transcribed to assure the rebirth of Masahiko's noble spirit in Amida's Gokuraku Pure Land" (figure 3b). A copy of the Sutra of the Dhärani of the Jubilant Corona (Bucchō sonshō daranikyō 佛頂 尊勝陀羅尼経), an esoteric text for the eradication of karmic obstacles and the prolongation of life, was also buried on the same day, and was similarly transcribed, according to the inscription, "so that the noble spirit of Masahiko become a buddha and attain the Way." ${ }^{17}$

In addition to the sutras, three high-quality mirrors made of a nickel-copper alloy included in the burial give visual and material expression to the petitioners'

17 Ibid. (no. 122). 

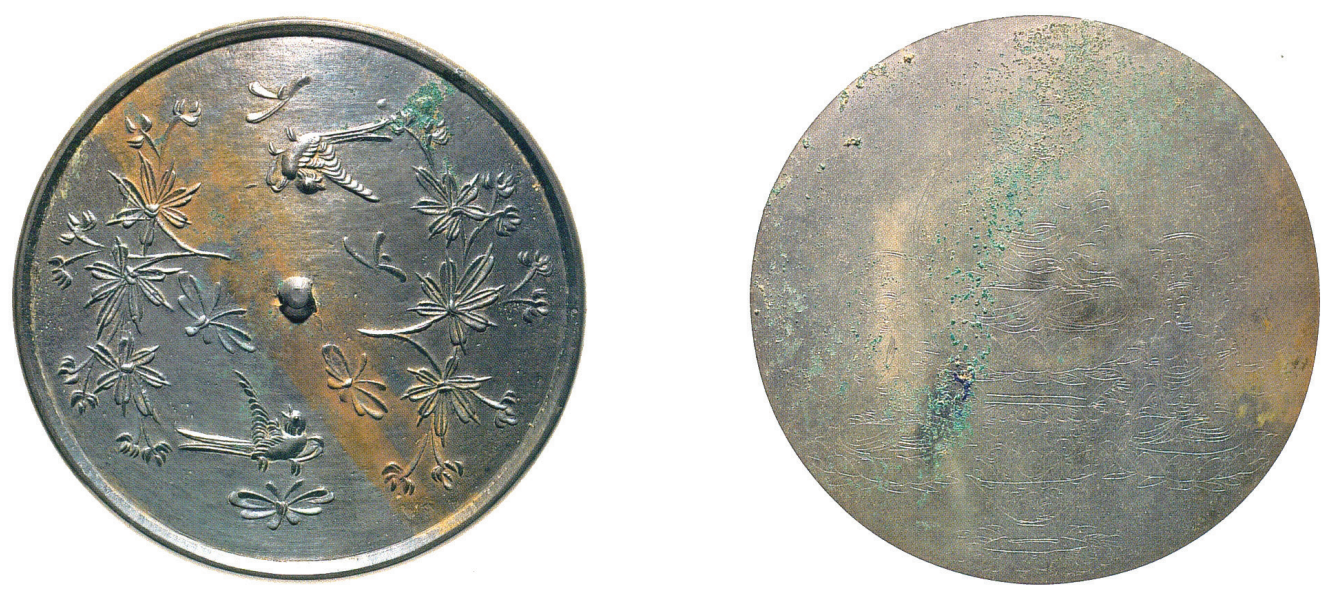

Figure 4. Mirror with images of Amida (front, on right) and birds and maple (back, on left). 1159, Heian period. Bronze. Diam. $13.4 \mathrm{~cm}$. Excavated from Mt. Asama Kyōgamine sutra mound no. 3, Ise, Mie Prefecture. Collection Kongōshōji, Mie Prefecture. From Nara Kokuritsu Hakubutsukan, Shinbutsu shūgō, p. 65, fig. 50-4.
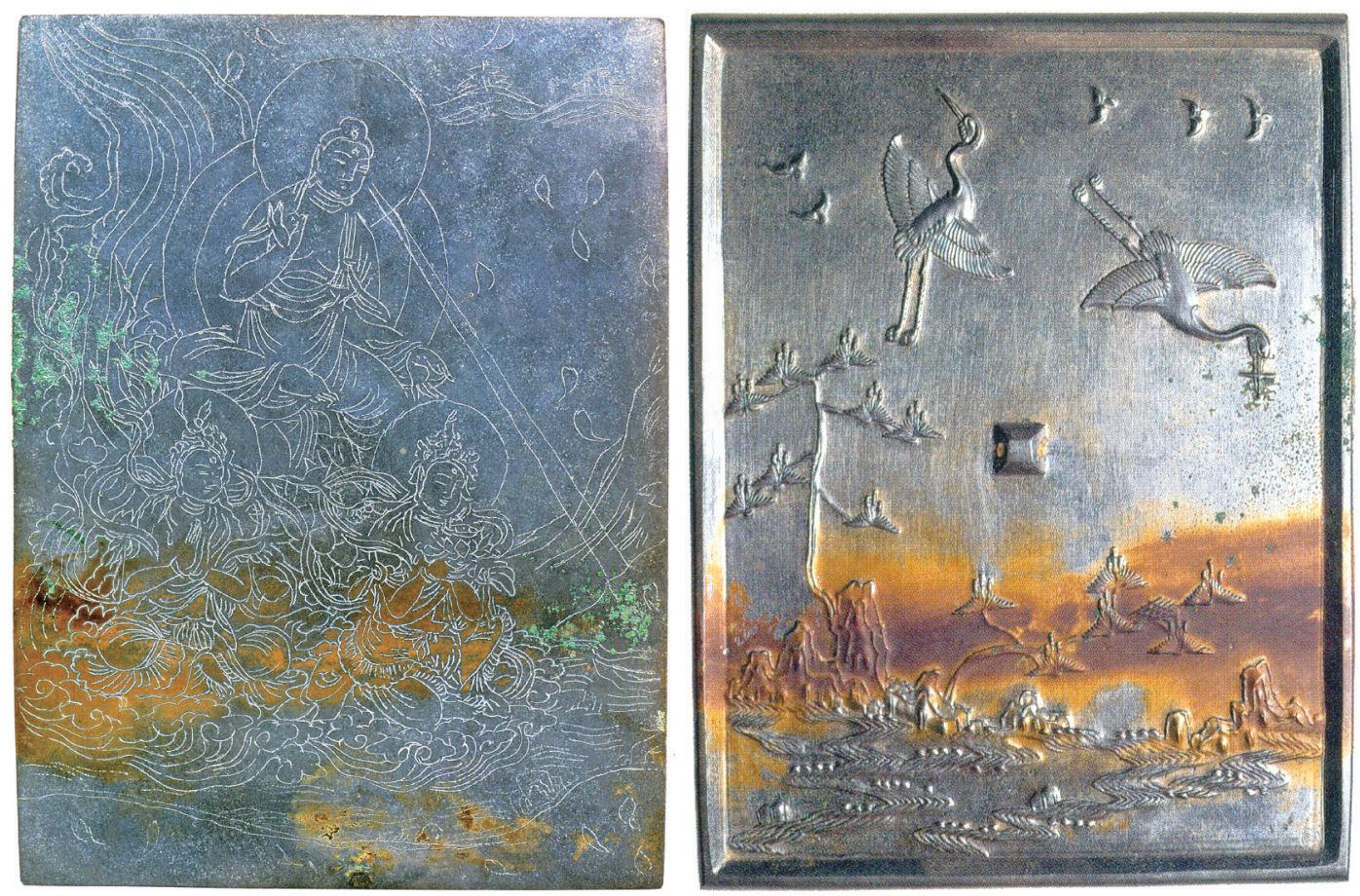

Figure 5. Mirror with images of descent of Amida triad (front, on left) and islands with cranes and pines (back, on right). 1159, Heian period. Bronze. $20 \mathrm{~cm} \times 14.7 \mathrm{~cm}$. Excavated from Mt. Asama Kyōgamine sutra mound no. 3, Ise, Mie Prefecture. Collection Kongōshōji, Mie Prefecture. From Tōkyō Kokuritsu Hakubutsukan, Ise jingū to kamigami no bijutsu, p. 59, fig. 26; and Nara Kokuritsu Hakubutsukan, Shinbutsu shūgō, p. 65, fig. 50-3. 

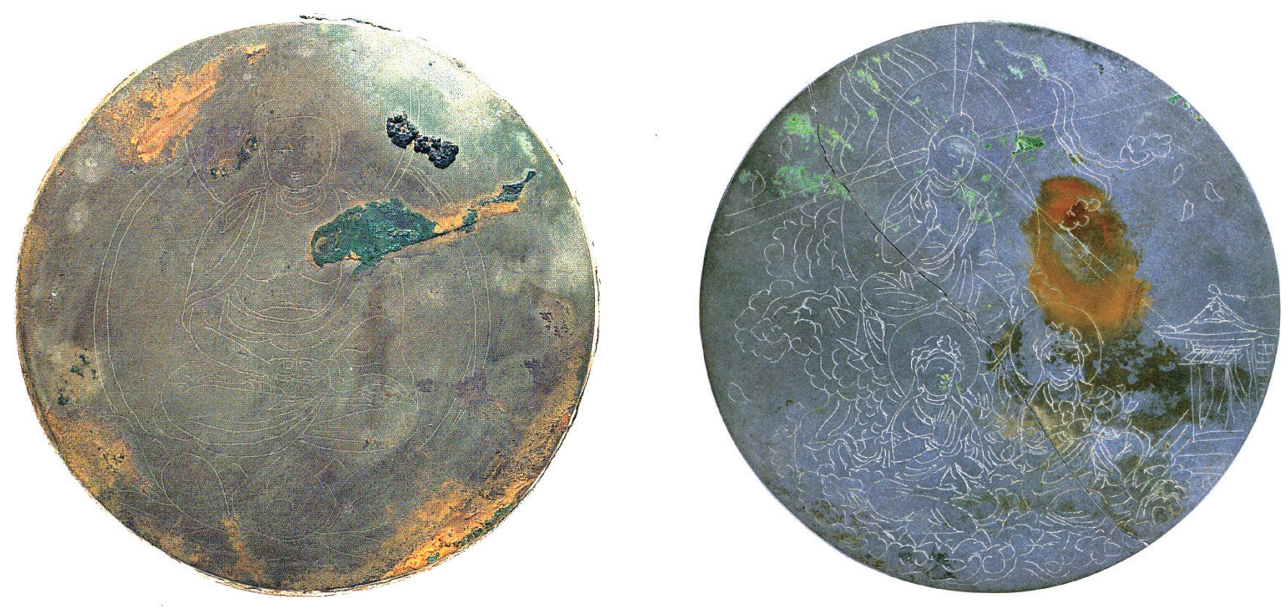

Figure 6. Mirror with images of Amida on two sides (back, on left; front, on right). 1159, Heian period. Bronze. Diam. $12.9 \mathrm{~cm}$. Excavated from Mt. Asama Kyōgamine sutra mound no. 3, Ise, Mie Prefecture. Collection Kongōshōji, Mie Prefecture. From Tōkyō Kokuritsu Hakubutsukan, Ise jingū to kamigami no bijutsu, p. 58, fig. 26; and Nara Kokuritsu Hakubutsukan, Shinbutsu shūgō, p. 65, fig. 50-5.

aspirations. Two of the mirrors are round, and the third rectangular; all bear images of Amida, the buddha of the Western Pure Land. The back of one of the round mirrors is decorated with embossed images of birds, butterflies, and sprigs of maple, and the front is incised with an image of a seated Amida attended by the bodhisattvas Kannon 観音 and Seishi 勢至 (figure 4).

The rectangular mirror offers a double vision of the afterlife. The back of the mirror depicts a landscape of a Daoist paradise with images of cranes and pines, both auspicious symbols of longevity, and islands of immortality rising from the sea, whereas the face of the mirror is incised with a welcoming descent (raigo 来迎) of Amida and his attendant bodhisattvas among swirling clouds and fluttering lotus petals (figure 5). A ray of light from Amida's forehead falls on a rocky coast and the base of a mountain beside the sea. Further in the background are pine trees atop mountains. The coastal setting of Amida's descent is appropriate to the burial site, a mountain overlooking the sea, and seems to offer a close-up of the more distant landscape depicted on the mirror's back.

A second round mirror is incised on both sides with images of Amida (figure 6). On the back side, the buddha of the Western Pure Land is shown seated alone on a lotus pedestal with hands held in a mudra of meditation. The front side depicts the very salvation that the burial was meant to assure. Amida is shown, attended by two bodhisattvas, descending amid clouds and flower petals, rays of light emanating from his halo, toward the open doors of a pavilion where a devotee-in this case Watarai Masahiko himself-receives the Buddha's light and is offered a lotus throne by Kannon, on which he will return with them to the Pure Land.

The families of the Watarai and Ōnakatomi priests, together with the nuns and monks who sought to effect and form karmic bonds with their Buddhist salvation through the production and interment of Buddhist texts, objects, and images, provide physical evidence for social networks that extended across devotional and lineal affiliation. They also offer a rare example of innovations in Buddhist iconography. The two mirrors depicting the welcoming descent, which were buried for the head priest of the Outer Shrine, are the earliest extant examples of the welcoming descent of an Amida triad in any medium. ${ }^{18}$

The choice of the Lotus Sutra, the scripture transcribed by the nuns of Jōshōji and Jōkakuji for the Pure Land rebirth of Watarai Masahiko, was entirely in keeping with the practices of sutra burials in the late Heian period (794-1185). The Lotus Sutra, a text that explicitly encourages its own preservation, enshrinement, and veneration, was the scripture interred most commonly.

18 Okazaki, Pure Land Buddhist Painting, p. 110. 


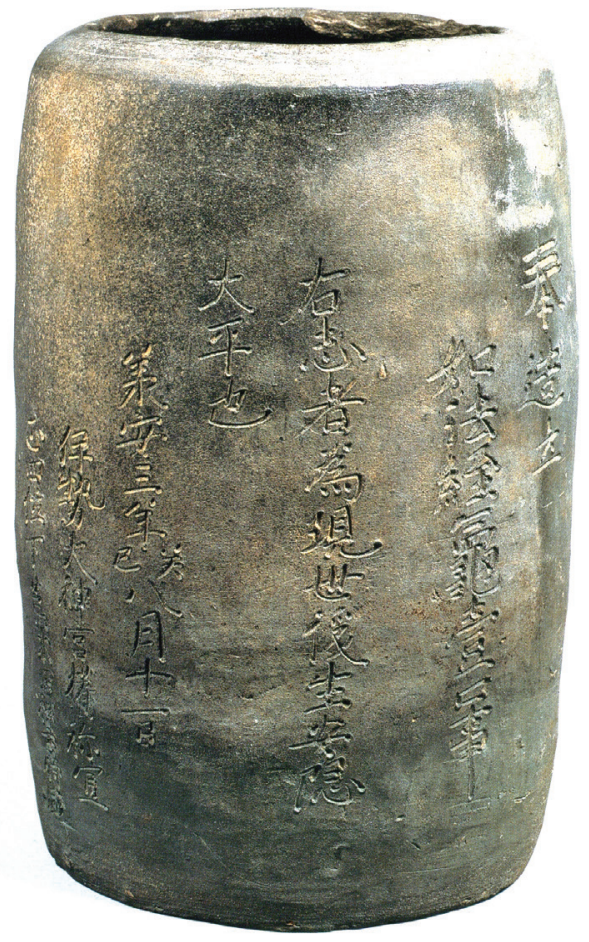

Figure 7. Sutra case. 1173, Heian period. Ceramic. Diam. $15.3 \mathrm{~cm}$, H $32.7 \mathrm{~cm}$. Excavated from Mt. Asama Kyōgamine sutra mound no. 3, Ise, Mie Prefecture. Collection Kongōshōji, Mie Prefecture. From Tōkyō Kokuritsu Hakubutsukan, Ise jingū to kamigami no bijutsu, p. 55 , fig. 27.

Like a number of other early Mahayana sutras, the Lotus Sutra claims that, because of its status as the textual corpus of the Buddha's teachings, it supersedes the corporal relic of the Buddha himself as the true body of the Buddhadharma. Indeed, the Lotus Sutra reserves the highest praise for those "who shall receive and keep, read and recite, explain, or copy in writing a single verse of the Scripture of the Blossom of the Fine Dharma, or who will look with veneration on a roll of this scripture as if it were the Buddha himself."19 In carrying out these scriptural instructions, the sponsors of the Ise burials enjoyed the combined merit of copying and protecting the sutra together with that of building a stupa in which to enshrine and venerate it. These practices were

19 Myōhō renge kyō, p. zob.

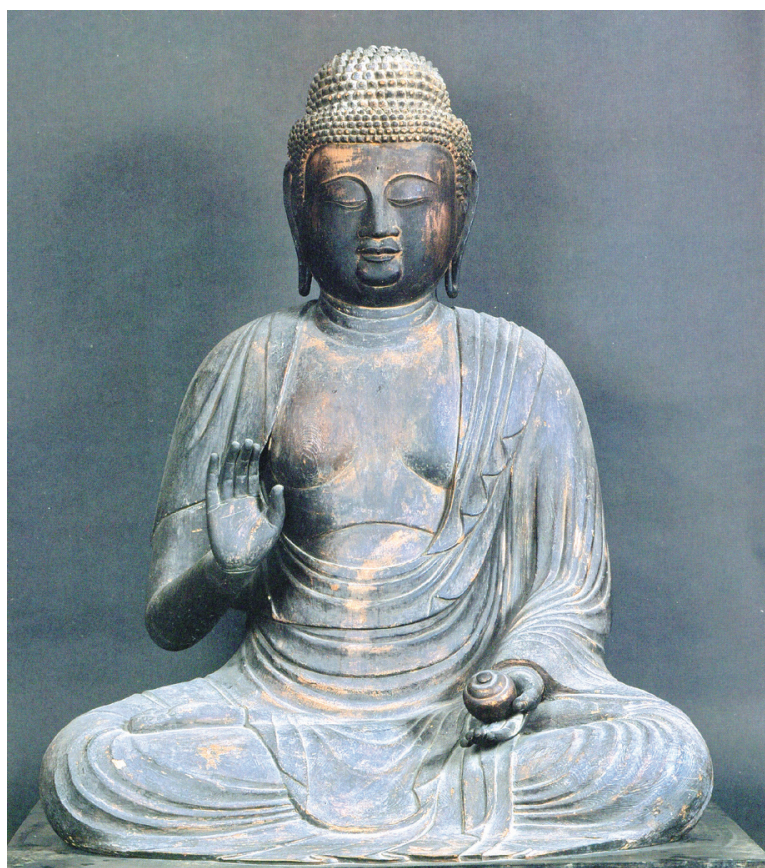

Figure 8a. Seated Yakushi Nyorai. 1145, Heian period. Wood with gold leaf. H 103.6 cm. Figs. 8a and 8b, Myōjōji, Mie Prefecture. Tōkyō Kokuritsu Hakubutsukan, Ise jingū to kamigami no bijutsu, p. 54, fig. 25.

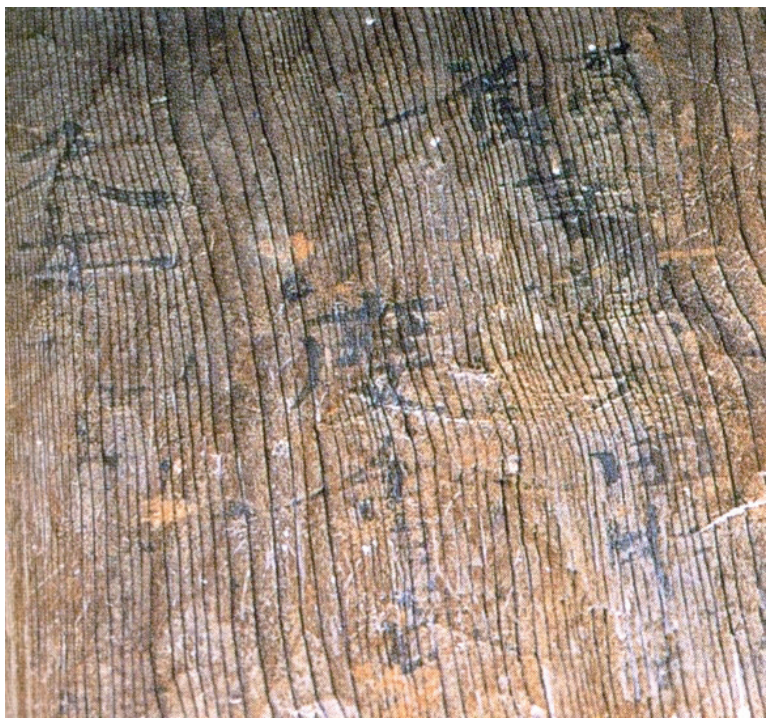

Figure 8b. Inscription on interior of seated Yakushi Nyorai, Myōjōji (fig. 8a).

particularly timely, as the buddha of the Lotus Sutra emphasizes that such methods of textual preservation and devotion are to be undertaken specifically "after my 
extinction, in an evil age." 20

Rebirth in Amida's Pure Land was also a common goal in Heian religious culture, and a goal advocated and idealized within the Lotus Sutra as well. The representation of Amida's welcoming descent incised on the interred mirrors follows a standard iconography found in countless texts and later paintings. Although the landscape elements depicted on the mirrors-mountains rising precipitously from the sea, island archipelagos viewed from afar-are the sort of idealized images commonly represented in scenes of Buddhist and Daoist paradises, they also share a decidedly local flavor: they are very like the sort of landscape viewed from the summit of Mt. Asama looking out toward Ise Bay. Further local references are to be found among the names of those involved in the burials. The Kyōgamine burials were not exclusively for the benefit of the Watarai and Ōnakatomi lineages. A ceramic sutra vessel dated Jōan 承安 3 (1173).8.11 excavated from Mt. Asama site 1 contained another copy of the Lotus Sutra transcribed and offered for "peace and tranquility in the present and future life" for “the Shrine Priest Arakida Tokimori 時盛, Senior Fourth Rank Lower Grade Priest of the Great Shrine of Ise" (figure 7). ${ }^{21}$ Although often portrayed as hereditary rivals in histories of Ise, the side-by-side burial of sutras transcribed for the Pure Land rebirth of leading priests of both the Watarai and Arakida lineages illustrates an intimacy in matters of Buddhist practice.

Another illustration of this is to be found within a seated image dated to 1145 of Yakushi Nyorai 薬師如 来, the Buddha of Healing, donated to Jōsenji 定泉寺, one of the eight temples of the sacerdotal lineages of the Ise Shrine, and now housed at the nearby temple of Myōjōji 明星寺 (figure 8a). The image was offered jointly by an Arakida shrine priest (kannushi 神主) and a member of the Watarai lineage, who may have been his wife. Their names appear side-by-side, inscribed on the interior of the image (figure $8 \mathrm{~b}$ ). ${ }^{22}$

\section{A Canon in Clay}

An example of even greater cooperation between priestly lineages is illustrated by tile sutras buried at the

\footnotetext{
20 Ibid., p. 31 a.

21 Seki, Heian jidai no maikyō to shakyō, p. 457 (no. 128).

22 Tōkyō Kokuritsu Hakubutsukan, Ise jingū to kamigami no bijutsu, p. 179.
}

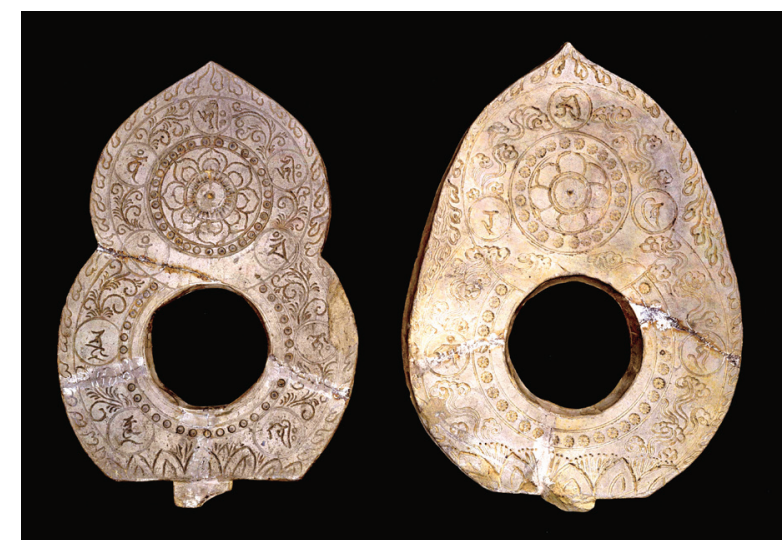

Figure 9. Mandorlas. 1174, Heian period. Terracotta. H $25.6 \mathrm{~cm}$. Excavated from the Komachi sutra mound, Ise City, Mie. Collection Tokyo National Museum, acc. no. J-36772, J-36773.

Komachi, Bodaisan, and Eitaizan sites near the Inner Shrine. More than 420 inscribed ceramic tiles, each measuring approximately twenty-five by thirty centimeters, were buried at the three sites between the fifth and seventh month of 1174 . An undertaking of such an enormous scale required the participation of many individuals, members of the Ōnakatomi, Isobe, Watarai, and Arakida lineages, as well as the funds, materials, and technologies necessary to produce, inscribe, and transport the sutra tiles. The sutras inscribed include the Lotus Sutra in 169 tiles; the Mahāvairocana Sutra (Dainichikyō 大日経) in 122 tiles; the Diamond Peak Sutra (Kongōchokyō 金剛頂経) in 40 tiles; the Tantra for Wondrous Achievement (Soshitchikyō 蘇悉地経) in 83 tiles; the Sutra that Transcends Principle (Rishukyō 理趣経) in 7 tiles; the Amida Sutra (Amidakyō 阿弥陀 経) in 4 tiles; and the Heart Sutra (Hannyashingyō 般若 心経) in a single tile. In addition to these sutras were also dharani texts, a Lotus Mandala in Siddham characters (a type of Sanskrit script introduced to Japan in the ninth century, in connection with esoteric Buddhism), a Diamond Realm and Womb Realm Mandala, a lotus pedestal, four mandorlas, and a seated Buddha image, all made of the same light gray clay (figure 9 shows two mandorlas). The selection of scriptures transcribed, like the presence of the Sutra of the Dhärani of the Jubilant Corona at Mt. Asama, reflects the Shingon affiliation of many of the lineage temples of the Ise priests.

A concern with the preservation of the Dharma throughout the dark days of the Final Age is evident in the material employed: fired clay of the sort used for 
roof tiles, a material intended to withstand the test of time. In their votive prayers, the participants refer explicitly to the Final Dharma. Inscriptions on three separate tiles and on one of the mandorlas announce the age as "the time of Sākyamuni's Final Dharma" 釈迦 末法之時. ${ }^{23}$ As with the Mt. Asama burials, the identities of those involved reveal the interwoven lives, afterlives, and aspirations of Ise's religious community. The names of two monks who played a leading role in the production and burial of the sutra tiles appear throughout the inscriptions as Shamon Nikan 沙門西観 and Kongōbushi Junsai 金剛仏子遵西. They are identified as monks from Mankakuji 万覚寺 in Irago 伊良, Atsumi District 渥美郡, Mikawa Province. Nikan and Junsai are listed in the colophons of the tile Lotus Sutra, Dainichikyō, Kongōchōkyō, Soshitsujikyō, and the Diamond Realm mandala. Nikan was also responsible for a seated buddha image that was dedicated in a memorial service for the monk's departed parents. Like the Mt. Asama burials, the tile sutras were dedicated to assuring the Pure Land rebirth of a head priest of the Ise Outer Shrine, in this case Watarai Tsuneyuki 度会常 行, who served as negi from 1144 until his death in 1160 at the age of seventy-four. ${ }^{24}$ Yet, as at Mt. Asama, the enormous ritual production offered the opportunity for members of Ise's other sacerdotal lineages to contribute to the Buddhist salvation of additional family members as well. One of the ceramic mandorlas was offered for a nun of the Ōnakatomi lineage. ${ }^{25}$ Another was offered by a male and female member of the Watarai lineage, together with Nikan and Junsai and six other monks, for the benefit of a member of the Isobe lineage. ${ }^{26} \mathrm{~A}$ third mandorla was offered for a member of the Arakida lineage. ${ }^{27}$ Three senior members of the Watarai lineage are listed among the names of those associated with the production of the Lotus Sutra tiles, but so, too, are members of the Isobe and Mononobe 物部 clans. The Dainichikyō, offered for the benefit of "Watarai Tsuneyuki's noble spirit," similarly includes the names of members of the Ōnakatomi and Arakida lineages.

The inscriptions suggest connections not only

\footnotetext{
23 Seki, Heian jidai no maikyō to shakyō, pp. 460 (no. 134), 461 (no. 134), 463 (no. 145), 466 (no. 160). Śākyamuni is the buddha of this world.

24 lbid. p. 461 (no. 135).

25 Ibid., p. 466 (no. 159)

26 Ibid., p. 467 (no. 160)

27 Ibid. (no. 162).
}

between and across sacerdotal lineages but also between the material resources and technologies of multiple shrine and temple institutions. Although the sutras were buried at Ise, they were not local products. According to inscriptions on the tiles, they were produced in Irago, Atsumi District, Mikawa Province. Irago, located at the tip of the Atsumi peninsula directly across Ise Bay, was a region covered with estates that supplied tribute and resources to the Ise Shrines. The growth of commended estates in the late twelfth century marked a decisive transformation of Ise's institutional base and economic status. ${ }^{28}$ Estates across the Atsumi peninsula, a site for ceramic production since the Kofun period (300-538), were commended to the shrines throughout the twelfth and thirteenth centuries. ${ }^{29}$ An inscription on one of the Komachi sutra tiles identifies "Watarai kannushi Tsuneyuki [as] the lord of the estate (mikuriya ryōshu 御厨領主)" where the tile was produced. Thus, the role of Irago's estates in the massive production of ceramic sutras, images, and objects for the Pure Land rebirth of the Ise priests also reveals the extent of Ise's institutional and territorial authority. Other excavated materials identify the Atsumi peninsula as the place of origin for the ceramic materials buried at Ise. An outer ceramic sutra case buried elsewhere at Ise is signed by a monk who identifies himself as "a resident of the shrine land of Kachi," an estate held by the Inner Shrine on the peninsula. Kachi 鍛治 (also written 加治), the site of numerous kilns, also produced lotus-form pedestals of the kind excavated from Komachi..$^{30}$ One of the ceramic mandorlas from Komachi is inscribed by Fujii Narishige 藤井成重 as "an offering of white clay, for rebirth in the Pure Land, at the time of Sankyamuni's Final Dharma, produced at Mankakuji in Irago, Atsumi Province." ${ }^{31}$

The ceramic sutra tiles, containers, mandorlas, and lotus-form pedestals buried at Ise, intended to ensure the Buddhist salvation of the priests of the Ise Shrines, thus were produced out of the local clay from estates controlled by these shrines on the Atsumi peninsula, manufactured and inscribed by artisans, scribes, and the monks Junsai and Nikan at Mankakuji, fired in the kilns of Irago, and transported, like any other tribute due, by boat across Ise Bay. This massive production of

\footnotetext{
28 Teeuwen and Breen, A Social History of the Ise Shrines, p. 60

29 Okamura, "Ise chihō ni okeru maikyō," p. 18.

30 lbid., p. 19

31 Seki, Heian jidai no maikyō to shakyō, p. 466 (no. 160).
} 
Buddhist texts - a canon cast in clay-was then buried underground at the Ise Shrines, to preserve the Dharma for the next 5.6 billion years, and also, according to the donative inscription, to secure for the shrine priests "the proper state of mind at the moment of death, rebirth in Amida's Pure Land, protection of the state in all ten directions, benefit and joy to all sentient beings, presence at the advent of the future buddha, Maitreya, and the proper performance of all Buddhist memorial services." ${ }^{2}$

The Buddhist texts, objects, and images buried at Ise in the twelfth century offer material evidence of an historical consciousness. For the members of the shrine's sacerdotal lineages-the Watarai, Arakida, Isobe, and Onakatomi-the sutra burials marked a crucial juncture in Buddhist history. They signaled, in the words of the inscriptions themselves, "the time of Sākyamuni's Final Dharma," a long age of religious decline, a downward descent in the perpetual cycle of Buddhist chronology until "the advent of the future buddha, Miroku." But the burials also mark a more personal kind of crisis in the life cycles of the families themselves: the transition from life to death and from death to rebirth. The burial of sutras was a common and communal response by the members of Ise's priestly elites who collaborated across differences of lineage and institution to address this confluence of the personal and the historical, a crisis of mortality in their familial lives and in the life of Buddhism, and an attempt to address the inevitability of impermanence.

For us today, the sutra burials at Ise call attention to a history of interrelations obscured by claims of separation. Such claims, legislated by the Meiji state, sought to restore Japan to a religious past it never had. This invented tradition required the erasure of Ise's religious history and the construction of a past untouched by Buddhism. Ise's sutra burials, however, reveal that beneath such recent ideological constructions lie earlier strata of religious complexity in which the priests of Ise turned to Buddhist texts, Buddhist images, Buddhist rituals, and Buddhist ritualists to address a time of crisis in their personal lives and in the history of their religion. In this sense, the sutra burials at Ise offer another kind of buried treasure, one that reveals the material and ritual culture of a place that we long thought we knew. Sutra burials, like so many time capsules, provide the corpus for an archeology of religious aspiration. They allow for an excavation of Ise's religious history that requires us to look deeper than modern claims of a uniform and unaltered tradition, and reveal a religious landscape not isolated from Buddhist traditions but deeply grounded therein.

\section{Reference List}

\section{- Primary Sources}

Mujū Ichien 無住一圓. Shasekishū 沙石集. NKBT 85. Myōhō renge kyō 妙法蓮華経 (Ch. Miaofa lianfa jing). T 262 9:1a-62c.

Shoku Nihongi 続日本紀. 4 vols. SNKT 12-16.

\section{- Secondary Sources}

Abe Yasurō. "Shintō as Written Representation: The Phases and Shifts of Medieval Shintō Texts." Cahiers d'Extreme-Asie 16 (2006-2007), pp. 91-117.

Andreeva, Anna. Assembling Shinto: Buddhist Approaches to Kami Worship in Medieval Japan. Harvard University Asia Center, 2017.

Hagiwara Tatsuo 萩原龍夫. “Ise jingū to bukkyō” 伊勢神 宮と仏教. In vol. 1 of Ise shinkō 伊勢信仰, ed. Hagiwara Tatsuo, pp. 231-39. Yūzankaku, 1985.

Iyanaga Nobumi. "Medieval Shintō as a Form of 'Japanese Hinduism': An Attempt at Understanding Early Medieval Shintō." Cahiers d'Extreme-Asie 16 (2006-2007), pp. 261-303.

Kodama Michiaki 小玉道明. Ise Yamada no gakyō 伊勢山 田の瓦経. Matsusaka: Hikari Shuppan, 2008.

Moerman, D. Max. "Chichū no Bukkyō: Ise jingū no chika kara no chōbō” 地中の仏教一伊勢神宮の地下からの 眺望, pp. 108-122. In Hen'yō suru seichi: Ise 变容する聖 地: 伊勢, ed. John Breen. Kyoto: Shibunkaku Shuppan, 2016.

Morrell, Robert E. Sand and Pebbles (Shasekishü): The Tales of Mujū Ichien, A Voice of Pluralism in Kamakura Buddhism. Albany, NY: SUNY Press, 1985.

Nara Kokuritsu Hakubutsukan 奈良国立博物館. Shinbutsu shūgō: Kami to hotoke ga orinasu shinkō to bi 神仏習 合:かみとほとけが織りなす信仰と美. Nara: Nara Kokuritsu Hakubutsukan, 2007. 
Okamura Hideo 奥村秀雄. “Ise chihō ni okeru maikyō” 伊 勢地方における埋経. Museum ミュジアム 167 (1965) pp. 14-22.

Okazaki, Jōji. Pure Land Buddhist Painting. Trans. Elizabeth ten Grotenhuis. New York: Kodansha International, 1977.

Seki Hideo 関秀夫. Heian jidai no maikyō to shakyō 平安時 代の埋経と写経. Tōkyōdō, 1999.

Seki Hideo. Kyōzuka to sono ibutsu 経塚とその遺物. Nihon no bijutsu 日本の美術 9:292 (1990).

Teeuwen, Mark, and John Breen. A Social History of the Ise Shrines: Divine Capital. London: Bloomsbury, 2017.

Teeuwen, Mark, and Hendrik van dere Veere. Nakatomi Harae Kunge: Purification and Enlightenment in LateHeian Japan. Munich: Iudicium Verlag, 1998.

Tōkyō Kokuritsu Hakubutsukan 東京国立博物館, ed. Ise jingū to kamigami no bijutsu 伊勢神宮と神々の美術。 Kasumi Kaikai, 2009. 